\title{
Diagnosis and Laparoscopic Repair of Obturator Hernia with Intestinal Obstruction
}

\author{
Intestinal Obstrüksiyona Neden Olan Obturatuar Herninin Laparoskopik Tanı ve Tedavisi
}

\author{
Erkan Somuncu', Fahri Gökçal2, Sinan Çarkman³, Kemal Peker ${ }^{1}$ \\ ${ }^{1}$ Department of General Surgery, Erzincan University Faculty of Medicine, Erzincan, Turkey \\ ${ }^{2}$ Clinic of General Surgery, Van District Training and Research Hospital Van, Turkey \\ ${ }^{3}$ Department of General Surgery, İstanbul University Cerrahpaşa Faculty of Medicine, ìstanbul, Turkey
}

\begin{abstract}
Obturator hernia is a very rare abdominal hernia that is located in the anterior pelvis. Patients apply to a hospital with a clinical intestinal obstruction table in this type of hernia. Prognosis in obturator hernia remains quite poor because of delayed diagnosis and surgical management. Nowadays, radiological techniques, especially computed tomography, are very advanced. Nevertheless, obturator hernia is a serious problem with its increased mortality, because it is detected quite hardly. We tried to offer an 82-year-old woman with acute abdomen that was considered on mechanic intestinal obstruction table for us in this article. Computed tomography is useful on these patients, just as it is useful in this article. For this reason, we scanned computed tomography and recognized a strangulated obturator hernia on the left. Afterwards, we planned a surgical operation and repaired the obturator hernia laparoscopically. The patient was transferred to the intensive care unit because of respiratory failure after the operation was finished. The patient, who was followed in the intensive care unit, died five days later because of acute respiratory failure. Obturator hernia is a rare cause of acute intestinal obstruction. Therefore, increased mortality rates should be remembered in elderly patients because of delayed diagnosis and accompanying chronic diseases. (JAREM 2014; 1: 31-4)
\end{abstract}

Key Words: Obturator hernia, laparoscopy, intestinal obstruction

\section{ÖZET}

Obturator herni çok ender rastlanan bir abdominal herni olup anterior pelvis yerleşimlidir. Bu herni tipinde hastalar klinik olarak mekanik intestinal obstrüksiyon tablosu ile hastaneye başvurabilmektedirler. Bu hastaların tanısındaki gecikme ve operasyona giden sürecin uzaması nedeniyle obturator herni de prognoz oldukça kötü seyretmektedir. Günümüzde radyolojik teknikler özelliklede bilgisayarlı tomografinin üstünlüğü çok gelişmiştir. Yine de obturator herni çok güç fark edilen ve bu nedenle de artan mortalite sebebiyle ciddi bir problemdir. Bu çalışmada acil servisimize akut batın ile başvuran ve intestinal obstrüksiyon ile ilişkili olduğunu düşündüğümüz 82 yaşındaki bir bayan hastayı sunmaya çalıştık. Bu çalışmada da olduğu gibi bilgisayarlı tomografi böyle hastalarda çok faydalı olmaktadır. Biz de bu nedenle bu hastada bilgisayarlı tomografi çektik ve tomografide sol strangule obturator herni varlığını farkedebildik. Daha sonra operasyon planlanan hastaya laparoskopik olarak herni onarımı yaptık. Hasta operasyondan sonra solunum yetersizliği nedeniyle yoğun bakım ünitesine transfer edildi. Beş gün sonra akut solunum yetersizliği nedeniyle yoğun bakımda takip edilen hasta vefat etti. Obturator herni akut intestinal obstrüksiyonun nadir sebeplerinden biridir. Bu nedenle yaşlı hastalarda tanının zorluğu ve eşlik eden kronik hastalıklarla birlikte artmış mortalite oranları her zaman akılda tutulmalıdır. (JAREM 2014; 1: 31-4)

Anahtar Sözcükler: Obturator herni, laparoskopi, intestinal obstrüksiyon

\section{INTRODUCTION}

Obturator hernia is a rare anterior pelvic floor hernia that occurs through the obturator canal, adjacent to the obturator vessels and nerve. It usually occurs in thin multiparous elderly women. People having chronically elevated intra-abdominal pressure are at high risk. Especially, two-thirds of the cases are in the seventh and eighth decades of life.

Characteristic complaints of these patients are often vague. Therefore, to diagnose and treat obturator hernia is quite arduous (1). Abdominal pain, vomiting, recurrent bouts of intestinal obstruction, Howship-Romberg sign, or a palpable upper thigh mass can be seen. However, symptoms are nonspecific in most cases. To diagnose obturator hernia, authors advocate different approaches. Some authors prefer early use of laparotomy, while others prefer preoperative non-invasive diagnostic methods, such as computed tomography (CT) or contrast radiographs (2).

We present a case of an elderly woman with an atypically symptomatic obturator hernia diagnosed and repaired laparoscopically.

\section{CASE PRESENTATION}

In December 2010, an 82-year-old female patient was admitted to the emergency room, having the complaints of abdominal pain with nausea and vomiting lasting for 3 days. By the physical examination, neither a palpable mass nor tenderness was noted on the lower abdominal quadrants. On laboratory results, we detected only a high white blood cell count, and there were no other abnormalities in biochemical parameters.

This case was presented as a poster at the 11th National Endoscopic Laparoscopic Surgery Congress, 2-6 October 2013, Bodrum/Muğla, Turkey. Bu olgu, 11. Ulusal Endoskopik Laparoskopik Cerrahi Kongresi'nde poster olarak sunulmuştur, 2-6 Ekim 2013, Bodrum/Muğla, Türkiye.

Address for Correspondence / Yazışma Adresi: Dr. Erkan Somuncu, Department of General Surgery, Erzincan University Faculty of Medicine, Erzincan, Turkey

Phone: +90 4462241224 E-mail: dr.somuncu@gmail.com
Received / Geliş Tarihi: 14.01.2014 Accepted / Kabul Tarihi: 03.03.2014 (C) Telif Hakkı 2014 AVES Yayıncıl Ik Ltd. Şti. Makale metnine www.jarem.org web sayfasından ulaşılabilir. C Copyright 2014 by AVES Yayıncllk Ltd. Available online at www.jarem.org 
Radiologically, iv contrasted CT scan revealed that she had an obturator hernia, giving rise to mechanical obstruction of the small bowel.

Based on these clinical and radiological findings, laparoscopy was the procedure we have chosen. On laparoscopic exploration, a left strangulated obturator hernia involving an approximately 2 $\mathrm{cm}$ small bowel with its antimesenteric side was determined. Fortunately, there was no ischemia, necrosis, or perforation of the intestine. We relieved an entrapped segment of intestine and repaired the defect of the loose tissue on obturator foramen by intracorporeal primary sutures.

Soon after the operation, she was passed to our service department. Next day, she had flatus, and oral nutrition was started. Her vital signs were normal and had no complaints. Following an uneventful postoperative course of 3 days, the patient had an acute respiratory failure. Although there was no radiological confirmation of pulmonary embolism, administration of a lowmolecular-weight heparin (enoxaparin $0.4 \mathrm{cc}$ ) was decided as a precaution. But, on the same day, the patient was transferred to the intensive care unit because of respiratory insufficiency and died on the $15^{\text {th }}$ postoperative day with an aggravated pulmonary ventilation-perfusion mismatch.

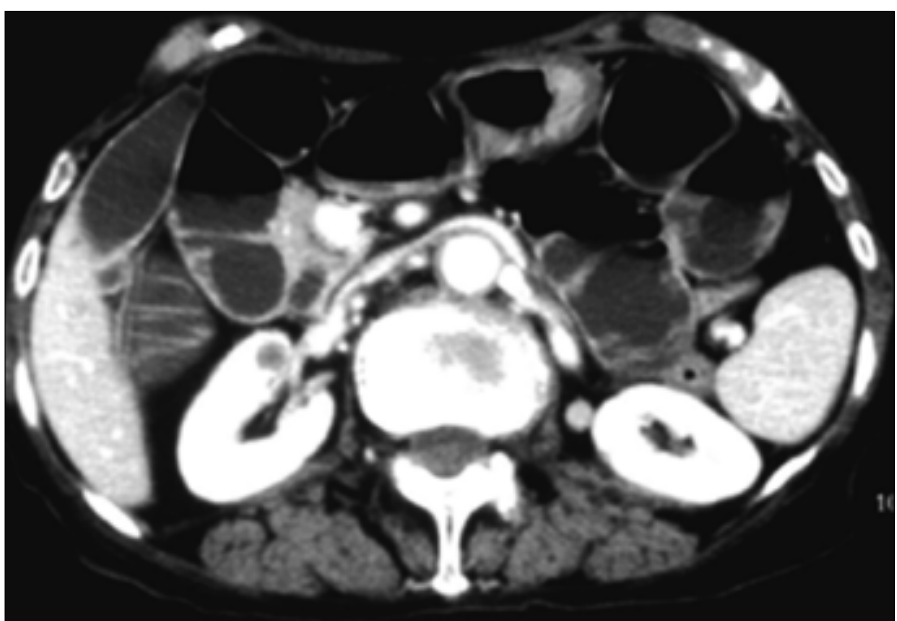

Figure 1. Dilated intestinal segments

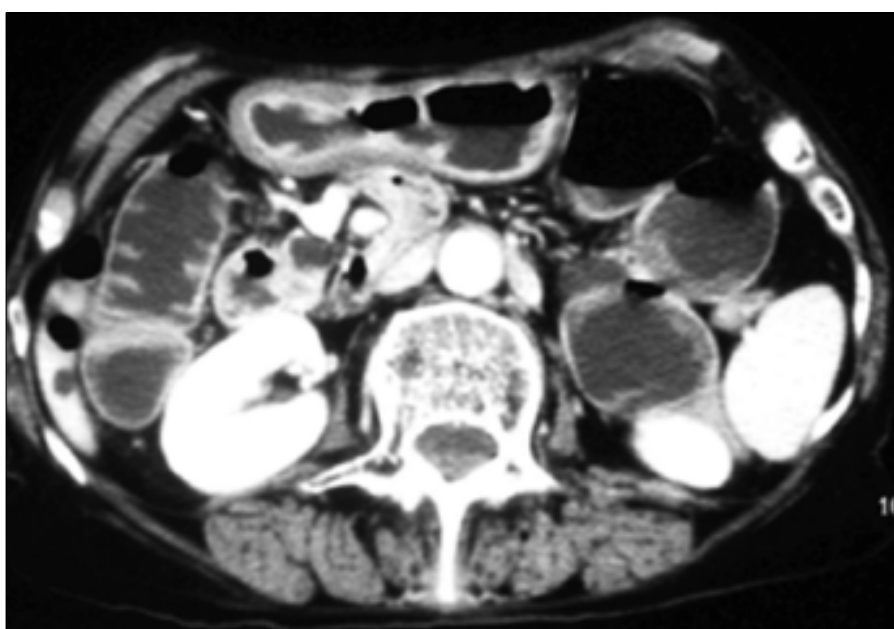

Figure 2. Air-fluid levels in bowels

\section{DISCUSSION}

To diagnose obturator hernia is quite tough because of its uncommon incidence, deep location, and infrequent specific signs and symptoms. The main cause of poor prognosis is delayed diagnosis in these patients. The obturator foramen is the hole created by the ischium and pubis bones of the pelvis through which nerves and blood vessels pass. The obturator canal is protected by femoral and pelvic muscles, accounting for the low incidence of herniation (3). It appears generally in debilitated elderly women, because they have a wide pelvic structure with large obturator canal, and they might lose their protective fat in the obturator canal $(4,5)$.

To diagnose obturator hernia is quite hard; on the other hand, it has some classical features. The first of them is a palpable mass in the groin when the patient is in supine position with the thighs are flexed, adducted, and rotated laterally. The second one is intestinal obstruction and previous attacks of bowel obstruction resolving spontaneously and the Howship-Romberg sign. The Howship-Romberg sign is reported to be present in 15\%-50\% of obturator hernia cases. The Howship-Romberg sign is characterized with medial thigh and hip pain, exacerbated by adduction and medial rotation of the thigh and relieved by flexion of the

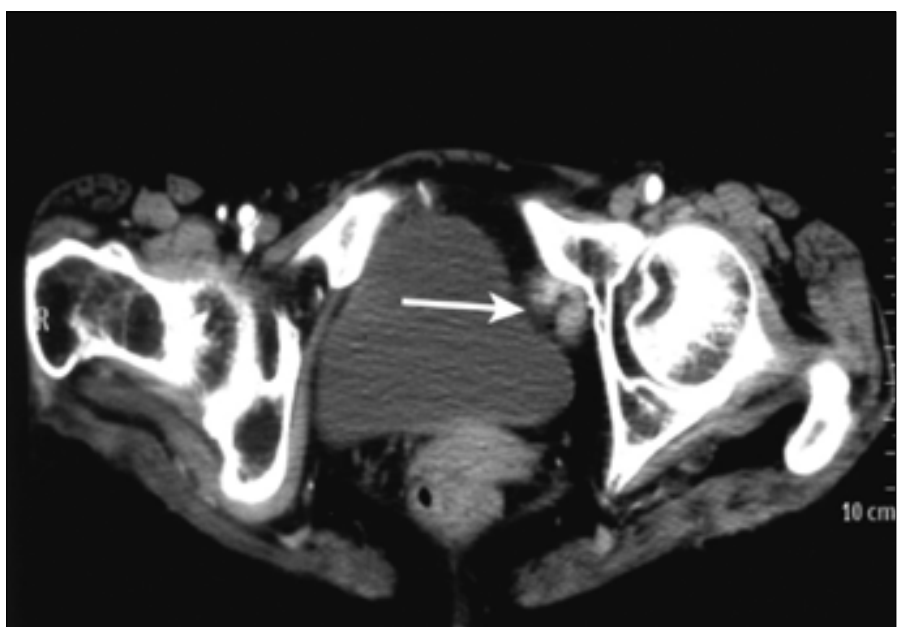

Figure 3. Left incarcerated ileal segment

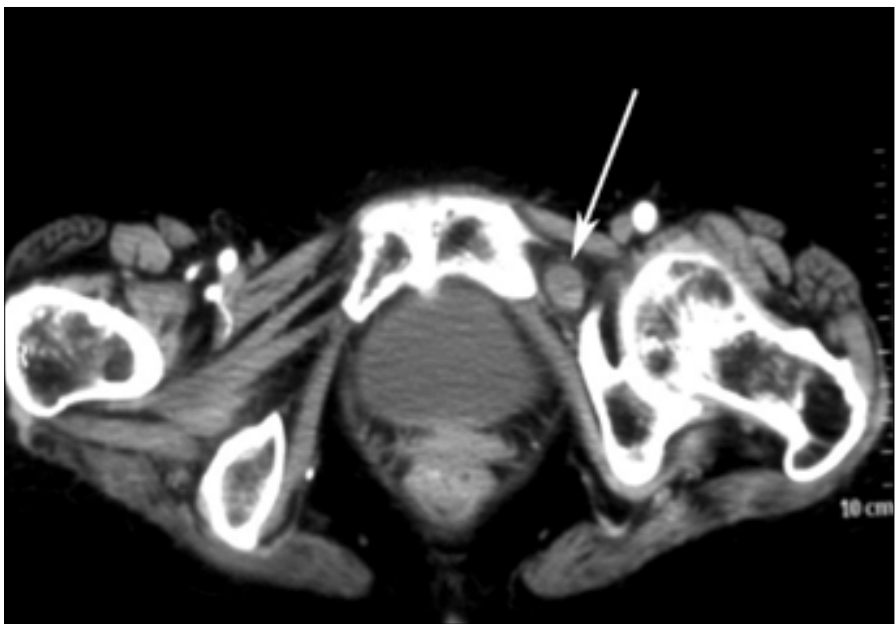

Figure 4. Left obturator hernia defect 
thigh. The patients are reported to present with intestinal obstruction. The characteristic clinical profile is known: emaciated old women with concomitant medical illness (6-9).

In our case, there was no clue about the pregnancies of this very thin and elderly woman. She had some abnormalities and some episodes of bowel obstruction with abdominal pain in her medical history. We detected this problem with physical examination and radioimaging techniques.

Rising intraabdominal pressure is used to describe obturator hernia. Some factors increase the pressure, such as constipation, kyphoscoliosis, pregnancy, and chronic lung disease. They might be the underlying reasons of herniation. The obturator hernia is rarely on the left side, because sigmoid colon tends to prevent the herniation (10). The diagnosis of the obturator hernia is often delayed until laparotomy, which is performed to treat the bowel obstruction or peritonitis. Diagnosis can be successfully achieved by barium enema fluoroscopy, herniography, or USG, but increasing evidence indicates that CT scanning has superior sensitivity and accuracy than the conventional methods in the preoperative diagnosis of obturator hernia. CT scanning could lead to rapid diagnosis and early surgical intervention, particularly in elderly patients presenting with intestinal obstruction of unknown origin $(11,12)$.

In our case, neither the Howship-Romberg sign nor an obviously inguinal palpable mass was noted, and the clinical presentation consisted solely of intestinal obstruction with acute abdomen CT imaging, allowing us to make a rapid and correct diagnosis and immediate operative intervention.

Surgical interventions, some of which can result with the resection of the intestine, are required in these cases. The obturator hernia may often occur with intestinal occlusion and strangulation (13). The surgical approach can be selected to diagnose. There are several ways to repair the obturator hernia. One of the surgical modalities is hernial sac ligation only; direct suture of the fascial defect is considered sufficient for small hernias with nonabsorbable sutures by using the periosteal fascia, bladder wall, or uterine fundus. The other technique is the mesh repair with laparoscopic method or laparotomy (14-16).

Our approach was laparoscopic repair. We relived a 2-cm-diameter entrapped small bowel in the obturator canal, because there was neither an intestinal occlusion nor strangulation. We set the entrapped segment back to the abdomen. Thereafter, simple closure of the pelvic orifice of the obturator canal with interrupted intracorporeal sutures was performed.

Elderly patients having many comorbid diseases are the main reason for the mortality of the obturator hernia. In our case, we made a laparoscopic repair, and the patient had been followed up in our service after surgery. Thereafter, on the third day of surgery, she was transferred to the intensive care unit because of respiratory failure, and she died on the $15^{\text {th }}$ postoperative day because of pulmonary insufficiency.

\section{CONCLUSION}

The obturator hernia is a very rare pelvic hernia that usually occurs in elderly, thin, multiparous women, and symptoms are nonspecific in most of the cases. The laparoscopic approach for diagnosis and treatment of obturator hernia is an effective alternative to conventional methods. Appropriate patient selection, right surgical judgment, and adherence to established principles of laparoscopic repair of the pelvic floor are essential to success. Being elderly and having comorbidities are causes of mortality. Scrutiny, early diagnosis, and treatment can be life-saving for these patients with acute abdomen.

Informed Consent: Written informed consent was obtained from patient and her relatives in this case.

Peer-review: Externally peer-reviewed.

Author Contributions: Concept - E.S., F.G.; Design - E.S.; Supervision F.G., S.Ç., K.P.; Funding - E.S.; Materials - E.S., F.G., S.Ç.; Data Collection and/or Processing - E.S., F.G.; Analysis and/or Interpretation - E.S., F.G., S.Ç., K.P.; Literature Review - E.S.; Writing - E.S., F.G.; Critical Review E.S., F.G., S.Ç., K.P.

Conflict of Interest: No conflict of interest was declared by the authors.

Financial Disclosure: The authors declared that this case has received no financial support.

Hasta Onamı: Yazılı hasta onamı bu olguya katılan hasta ve yakınlarından alınmıştır.

\section{Hakem Değerlendirmesi: Dış bağımsız.}

Yazar Katkıları: Fikir - E.S., F.G.; Tasarım - E.S.; Denetleme - F.G., S.Ç., K.P.; Kaynaklar - E.S.; Malzemeler - E.S., F.G., S.Ç Veri toplanması ve/veya işlemesi - E.S., F.G.; Analiz ve/veya yorum - E.S., F.G., S.Ç., K.P.; Literatür taraması - E.S.; Yazıyı yazan - E.S., F.G.; Eleştirel Inceleme - E.S., F.G., S.Ç., K.P.

Çıkar Çatışması: Yazarlar çıkar çatışması bildirmemişlerdir.

Finansal Destek: Yazarlar bu çalışma için finansal destek almadıklarını beyan etmişlerdir.

\section{REFERENCES}

1. Lo CY, Lorentz TG, Lau PW. Obturator hernia presenting as small bowel obstruction. Am J Surg 1994; 167: 396-98. [CrossRef]

2. Hsu CH, Wang CC, Jeng LB, Chen MF. Obturator hernia: a report of eight cases. Am Surg 1993; 59: 709-11.

3. Gray SW, Skandalakis JE, Soria RE, Row JS. Strangulated obturator hernia.Surgery 1974; 75: 20-7.

4. Yip AW, Ah Chong AK, Lam KH. Obturator hernia: a continuing diagnostic challenge. Surgery 1993; 113: 266-9.

5. Naude G, Bongard F. Obturator hernia is an unsuspected diagnosis. Am J Surg 1997; 174: 72-5. [CrossRef]

6. Bryant TI, Umstot RK Jr. Laparoscopic repair of an incarcerated obturator hernia. Surg Endosc 1996; 10: 437-8. [CrossRef]

7. Roston AD, Rahin M, Eng A, Dannenberg AJ. Strangulated obturator hernia: a rare cause of small bowel obstruction. Am J Gastroenterol 1994; 89: 277-8.

8. Bergstein JM, Condon RE. Obturator hernia: Current diagnosis and treatment. Surg 1996; 119: 133-6. [CrossRef]

9. Hsu CH, Wang CC, Jeng LB, Chen MF. Obturator hernia: A report of eight cases. Am Surg 1993; 59: 709-11. 
10. Kozlowski JM, Beal JM. Obturator hernia : An elusive diagnosis.Arch Surg 1977; 112: 1001-2. [CrossRef]

11. Ijiri R, Kanamaru $H$, Yokoyama $H$, Shirakawa M, Hashimoto $H$, Yoshina G. Obturator hernia: The usefulness of computed tomography in diagnosis. Surgery 1996; 119: 137-40. [CrossRef]

12. Cubillo E. Obturator hernia diagnosed by computed tomography. AJR Am J Roentgenol 1983; 140: 735-6. [CrossRef]

13. Arbman G. Strangulated obturator hernia. A simple method for closure. Acta Chir Scand 1984; 150: 337-9.
14. Shipkov CD, Uchikov AP, Grigoriadis E. The obturator hernia: Diffucult to diagnose, easy to repair. Hernia 2004; 8: 155-7. [CrossRef]

15. Tucker JG, Wilson RA, Ramshaw BJ, Mason EM, Duncan TD, Lucas GW. Laparoscopic herniorraphy: tecnical concerns in prevention of complications and early recurrence.Am Surg 1995; 61: 36-9.

16. Tchupetlowsky S, Losanoff J, Kjossev K. Bilateral obturator hernia: A new technique and a new prosthetic material for repair - a case report and rewiew of the literature. Surgery 1995; 117: 109-12. [CrossRef] 